\section{Lead Poisoning}

SIR,-I would like to comment on the letters from Dr. M. K. Williams (2 September, p. 586) and Dr. H. A. Waldron (30 September, p. 827).

The basis of the statement by Lane and others ${ }^{1}$ was that lead poisoning was a clinical diagnosis. The acceptable levels of coproporphyrin and of $\alpha$-aminolaevulinic acid in urine recognize that lead is affecting enzyme systems without producing symptoms. The study by Hernberg ${ }^{2}$ shows at what blood level the enzyme $\alpha$-aminolaevulinic acid dehydrase is affected by lead but does not affect the well-being of individuals. If one follows Dr. Waldron's reasoning to its logical conclusion the limit for lead in blood should be zero.

What is confusing about the paper by Dr. A. D. Beattie and colleagues (27 May, p. 488) is that clinical lead poisoning is diagnosed on a single symptom without any other evidence or the exclusion of other causes. In three cases the coproporphyrin in urine is within the normal range for people not exposed to lead. Urinary $\alpha$-aminolaevulinic acid levels in four cases are within internationally accepted limits of safety, and the same is true of blood lead levels. I seems strange that in looking after severa thousand lead-workers for over 20 years have not come across any symptoms due to lead where biological data was at similar levels to those found by Beattie and colleagues.

It is most important, particularly when carrying out blood lead analysis, to have interlaboratory trials. The results found in this study cause me to consider whether the biological data are comparable with those of much of the published work.-I am, etc.,

Prestbury, Cheshire

D. MaLcolm

1 Lane, R. E., et al., British Medical fournal, 1968, 2 4ernberg, S., and Nikkanen, J., Lancet, 1970, 1, 63.

63. 1972, 2, 488 .

\section{Bone Disease in Chronic Renal Failure}

SIR,-The experience of Dr. M. C. Bishop and others (16 September, p. 664) with respect of histological bone disease and chronic renal failure is a valuable contribution on this subject and represents another variation within the spectrum of renal osteodystrophy. However, though a control series has not been included and the criteria of normality have not been laid down yet, in half of the patients the bones were recognized as abnormal at the start of dialysis. By contrast, in the Hammersmith series ${ }^{1}$ all the patients at the start of dialysis were shown to have abnormal quantities of osteoid or resorption or both, and further work since then has confirmed this finding when compared to an adequate control series matched for age and sex. $^{2}$

The methodology of quantitation is not detailed, and though by implication it is only trabecular bone that has been analysed it must be said that the inadvertent inclusion of the transitional $z^{2} e^{3}$ in the analysis could affect the result. Furthermore, defining osteitis fibrosa as "profuse" quantities of fibrous tissue extending from resorption cavities into the marrow space is imprecise in a histoquantitative setting. If histological studies are to provide evidence for a regional variation in renal osteodystrophy within the United Kingdom then a plea can be made for the standardization of techniques used in different centres.

The Oxford group's finding that the bones of the three patients who had both kidneys removed were histologically indistinguishable from the bones of those patients whose kidneys had not been removed is not unexpected. Fraser and Kodicek $^{4}$ have shown that the conversion of the vitamin $D$ metabolite 25hydroxycholecalciferol to the active metabolite 1,25-dihydroxycholecalciferol requires renal enzymes. In end-stage renal failure, when the nephrons have ceased to function, it is not unreasonable to suppose that the enzyme systems are also functionless so the removal or otherwise of such kidneys can hardly be expected to alter the situation materially from the point of view of renal osteodystrophy. Indeed, at nephrectomy carried out on dialysis patients one frequently finds nothing more than a shrunken reniform mass at the ton of the ureter which quite clearly is functionless.

Evidence in support of the work of Fraser and Kodicek is now emerging and this is based on the sequential histoquantitative analysis of bone biopsies from successfully transplanted patients. Preliminary studies from Hammersmith Hospital, which will be reported in full later, indicate that irrespective of the changes while on dialysis regression of the pretransplant renal osteodystrophy has been most marked in those patients with better-than-average renal function, and this histological improvement has continued provided that renal function has not deteriorated. ${ }^{5}$ Conversely, the histological bone changes are less striking in the bones of those patients whose graft function is either fair or poor. Though after successful transplantation the bones in most patient are seen to heal in varying degrees from the point of view of conventional renal osteodystrophy, there are a few patients whose bones may be adversely affected by the drugsnamely, steroids-which are required to keep the graft from rejecting.

The importance of good tissue compatibility is reflected in the bone findings of those patients who have received a graft from a live, related donor. In two such patients, histological improvement is still taking place after five years-I am, etc.

RaYMond N. P. CARROLL

Manchester Royal Infirmary,

Manchester

1 Carroll, R. N. P., Tha Aung, Williams, E. D. and Shackman, R., Proceedings of the Europea Dialysis and Transplant Association, 1969, 6,

2 Doyle, F. H., Tha Aung, Carroll, R. N. P., Williams, E. D., and Shackman, R, British Williams B D Proceedings of 225.

Williams, E. D., Proceedings of the Royal Society 4 Fraser, D. R., Kodicek, E., Nature, 1970, 228, 5 Carroll, R. N. P., M.Ch. thesis in preparation.

\section{Fat Atrophy due to Insulin}

SIR,-Dr. J. M. Stowers (14 October, p. 98) suggests that diabetics can avoid unsightly fat atrophy by not injecting insulin too frequently into the same site. I think this is good advice, though not always successful. I have seen fat atrophy develop in areas remote from the sites where insulin has been injected.

Once local lipodystrophy has developed the best treatment is that first recommended by Collens 1 -namely, that insulin should be injected directly into the atrophic areas. More recently Watson and Calder ${ }^{2}$ extended this technique by using neutral insulin (Actrapid or Rapitard), which has a pH of $\mathbf{7 \cdot 4}$, in place of more commonly used insulins which are considerably more acid. Certainly in my own experience this routine can be strikingly successful in filling out lipodystrophic pits, sometimes within a few months. -I am, etc.,

London $\mathbf{W} .1$

ARNOLd BLOOM

1 Collens, W. S., Boas, L. C., Zilinsky, J. D., and Mreenwald, J.' J., New England foumal of

Watson, B. M., and Calder, J. S., Diabetes, 1971, 20,628 .

\section{Middle Class Syndrome}

SIR,-I have had a number of cases of this condition recently and I am very concerned about its recent increase. The syndrome consists of an individual who consults a professional colleague without due reference from his family doctor. Usually the referral is made through a mutual friend of the consultant and the patient, and from there investigations and sometimes treatment are carried out without the family doctor's prior knowledge.

On other occasions three or four separate consultations may be sought by the individual, and the family doctor is left with a series of different and conflicting advices about the same condition for which he, in the first instance, has been consulted and a line of approach, including recommended consultations, suggested. This leads to a feeling and sense of a lack of confidence and cannot possibly do the doctor-patient relationship any good at all.

The name of the syndrome (middle class syndrome) is not my personal term but that of a member of the staff of a well-known teaching hospital who rang me telling me that they were going to see one of my patients. When I objected, indicating that the patient had already been fully investigated at another teaching hospital, I was mildly told that this was yet another case of the middle class syndrome. This syndrome can, I am sure, be eliminated completely from our experience provided all members of the medical profession maintain their ethical code one with another.-I am, etc.

D. J. R. MORGAN

Walton-on-Thames,

Surrey

\section{Candidates for Coronaries}

SIR,-Your leading article on predicting coronary artery disease (7 October, p. 3) admits the considerable limitations of the Cambridge case-control study of 100 patients" but states that "even when all the information was taken into account its predictive value [for coronary artery disease] was weak." You conclude by mentioning that this underlines the extent of our ignorance about the causes of occlusive arterial disease.

While not wishing to discourage a respectful humility towards absolute knowledge of causation, we would suggest that some of the near-causal factors are sufficiently well- 